\title{
Correction to: A multicomponent intervention for the management of chronic pain in older adults: study protocol for a randomized controlled trial
}

Sheung-Tak Cheng ${ }^{1,2^{*}}$, Ka Long Chan ${ }^{1}$, Rosanna W. L. Lau ${ }^{1,2}$, Monique H. T. Mok ${ }^{3}$, Phoon Ping Chen ${ }^{4}$, Yu Fat Chow ${ }^{5}$, Joanne W. Y. Chung ${ }^{1}$, Alexander C. B. Law ${ }^{6}$, Jenny S. W. Lee', Edward M. F. Leung ${ }^{8}$ and Cindy W. C. Tam ${ }^{9}$

Correction to: Trials 18, 528 (2017) https://doi.org/10.1186/s13063-017-2270-3

Following the publication of the original article [1], we were notified that that the last name of the third author was incorrect.

- Originally published name: Rosanna W. L. Lam

- Corrected name: Rosanna W. L. Lau

The original article has been corrected.
${ }^{9}$ Department of Psychiatry, North District Hospital, 9 Po Kin Road, Sheung Shui, New Territories, Hong Kong.

Published online: 25 November 2021

\section{Reference}

1. Cragg, et al. A multicomponent intervention for the management of chronic pain in older adults: study protocol for a randomized controlled trial. Trials. 2017;18:528. https://doi.org/10.1186/s13063-017-2270-3.

\begin{abstract}
Author details
'Department of Health and Physical Education, The Education University of Hong Kong, 10 Lo Ping Road, Tai Po, New Territories, Hong Kong. ${ }^{2}$ Department of Clinical Psychology, Norwich Medical School, University of East Anglia, Norfolk NR4 7TJ, UK. ${ }^{3}$ Department of Rehabilitation and Extended Care, Kowloon Hospital, 147A Argyle Street, Kowloon, Hong Kong. ${ }^{4}$ Department of Anesthesiology \& Operating Services, Alice Ho Miu Ling Nethersole Hospital, 11 Chuen On Road, Tai Po, New Territories, Hong Kong. ${ }^{5}$ Department of Anesthesiology \& Operating Theatre Services, Queen Elizabeth Hospital, 30 Gascoigne Road, Kowloon, Hong Kong. ${ }^{6}$ Department of Medicine and Geriatrics, Princess Margaret Hospital, 2-10 Princess Margaret Hospital Road, Lai Chi Kok, Kowloon, Hong Kong. ${ }^{7}$ Department of Medicine, Alice Ho Miu Ling Nethersole Hospital, 11 Chuen On Road, Tai Po, New Territories, Hong Kong. ${ }^{8}$ Department of Medicine and Geriatrics, United Christian Hospital, 130 Hip Wo Street, Kwun Tong, Kowloon, Hong Kong.
\end{abstract}

The original article can be found online at https://doi.org/10.1186/s13063017-2270-3.

* Correspondence: takcheng@eduhk.hk

'Department of Health and Physical Education, The Education University of Hong Kong, 10 Lo Ping Road, Tai Po, New Territories, Hong Kong

${ }^{2}$ Department of Clinical Psychology, Norwich Medical School, University of East Anglia, Norfolk NR4 7TJ, UK

Full list of author information is available at the end of the article

(c) The Author(s). 2021 Open Access This article is licensed under a Creative Commons Attribution 4.0 International License, which permits use, sharing, adaptation, distribution and reproduction in any medium or format, as long as you give appropriate credit to the original author(s) and the source, provide a link to the Creative Commons licence, and indicate if changes were made. The images or other third party material in this article are included in the article's Creative Commons licence, unless indicated otherwise in a credit line to the material. If material is not included in the article's Creative Commons licence and your intended use is not permitted by statutory regulation or exceeds the permitted use, you will need to obtain permission directly from the copyright holder. To view a copy of this licence, visit http://creativecommons.org/licenses/by/4.0/. The Creative Commons Public Domain Dedication waiver (http://creativecommons.org/publicdomain/zero/1.0/) applies to the data made available in this article, unless otherwise stated in a credit line to the data. 